\title{
Synthesis and Preliminary Biological Evaluation of a New Pyridocar- bazole Derivative Covalently Linked to a Thymidine Nucleoside as a Potential Targeted Antitumoral Agent. I
}

\author{
Carmela Saturnino, ${ }^{a}$ Mariafrancesca Buonerba,,${ }^{a}$ Gianpiero Boatto, ${ }^{b}$ Maria Pascale, ${ }^{a}$ \\ Ornella Moltedo, ${ }^{a}$ Lorenzo De Napoli, ${ }^{c}$ Daniela Montesarchio, ${ }^{c}$ Jean-Charles Lancelot, ${ }^{d}$ and \\ Paolo de CAPRARIIS *,a \\ ${ }^{a}$ Dipartimento di Scienze Farmaceutiche, Università degli Studi di Salerno; Via Ponte Don Melillo, 84084 Fisciano, \\ Salerno, Italy: ${ }^{b}$ Dipartimento Farmaco Chimico Tossicologico, Università degli Studi di Sassari; Via Muroni $n^{\circ} 23,07100$ \\ Sassari, Italy: "Dipartimento di Chimica e Biochimica, Università degli Studi di Napoli "Federico II"; via Cynthia 4, \\ 80126 Napoli, Italy: and ${ }^{d}$ Centre d'Etudes et de Recherche sur le Medicament de Normandie (C.E.R.M.N.), UFR des \\ Sciences Pharmaceutiques; 1 rue Vaubenard,14032 Caen Cedex, France.
}

Received September 24, 2002; accepted April 23, 2003

\begin{abstract}
The therapy of human cancer is one of the more pursued goals by medicinal chemistry research. Most of the compounds clinically used as a treatment owe their efficacy to their cytotoxic interaction (direct or indirect) with nuclear DNA. This interaction results in the inhibition of DNA synthesis and the degradation of nucleic strands. Ellipticine is a naturally occurring $6 \mathrm{H}$-pyrido[4,3-b]carbazole alkaloid endowed with antitumor activity, and several ellipticine derivatives have been used in clinical trials. We previously reported some 1,4-dimethyl-9H-carbazole derivatives structurally related to ellipticine. The purpose of our research was to transform the pyridocarbazole in a prodrug so that it would have more penetration in the tumor cells and block their replication. Our prodrug is slowly hydrolyzed in human plasma in the corresponding acid. From these preliminary results, we deduce that our compound can block cellular replication. Our hypothesis is that the antitumoral activity is probably related to the induction of damage to DNA, without cellular lysis in the short term.
\end{abstract}

Key words ellipticine; anticancer; cytotoxicity

Ellipticine is a naturally occurring alkaloid of the $6 H$-pyridocarbazole family; this compound and its derivatives are endowed with antitumor properties. They are DNA intercalating molecules and their high DNA binding affinity is thought to be responsible in part for these pharmacological properties. $^{1,2)}$ 5,11-Dimethyl-6H-pyrido[3,2- $\left.b\right]$ carbazole derivatives, which are very similar in their structure to ellipticine (Fig. 1), bearing either a fluorine, a bromine, or a chlorine atom in the 9 position and differently substituted on the pyridine ring, have been synthesized in our laboratories and its antitumoral activity was tested in in vitro and in vivo. ${ }^{3,6)}$ With the aim of improving its pharmacokinetic properties, mainly enhancing cellular uptake in tissues where nucleoside receptors are present, we have designed and synthesized a new pyridocarbazole derivative in which the aromatic polycyclic moiety is linked to the 5 position of a thymidine nucleoside through an amido linkage (Charts 1,2), thus exploiting the nucleosidic residue as molecular carrier.,11) The synthesis of target compound $\mathbf{5}$ is illustrated in Chart 2. As the first step, ester $\mathbf{1}$ was treated with a stoichiometric amount of $\mathrm{NaOH}$ in pyridine, and after $12 \mathrm{~h}$ at room temperature, was transformed carboxylic acid 2 in $70 \%$ yield after chromatography. It was not possible to force this reaction to completeness, since prolonged basic treatment, higher temperatures, or the addition of more base in all cases led to a complex mixture of very polar compounds, which, according to ${ }^{1} \mathrm{H}$ - and ${ }^{13} \mathrm{C}-\mathrm{NMR}$ analysis, were the result of the opening of the heterocyclic system in 1. However, under the cited conditions for the basic hydrolysis of $\mathbf{1}$, unreacted starting material could be recovered in $10 \%$ yield and reused. Compound $\mathbf{2}$ was then reacted with 5-deoxy, 5-amino, 3'-O-t-butyldimethylsilyl (TBDMS)-thymidine 3, which was synthesized from thymi- dine in four steps in $75 \%$ overall yield (Chart 1 ), according to published procedures. ${ }^{4)}$ The best coupling yields were obtained using the system benzotriazol-1-(yloxy)tris(pyrolidino)phosphoniumhexafluorophosphate/1-hydroxybenzotriazol (PyBop/HOBt) as the condensing agent in anhydrous $N, N$-dimethylformamide/ $N, N$-diisopropylethylamine (DMF/DIEA), leading to compound 4 in $75 \%$ yield after purification. The successive treatment of $\mathbf{4}$ with the classic desilylating reagent TBAF in tetrahydrofuran (THF) to remove the TBDMS group led only to degradation products; however, the 3-OH group could be successful deprotected, but in low yield ( $32 \%$ after chromatography) with the addition of $\mathrm{Et}_{3} \mathrm{~N} \cdot 3 \mathrm{HF}$ in anhydrous THF. The purity and structure of all synthesized compounds were ascertained by ${ }^{1} \mathrm{H}$ - and ${ }^{13} \mathrm{C}$ NMR analysis as well as by mass spectral data.<smiles>Cc1c2ccncc2c(C)c2c1[nH]c1ccccc12</smiles>

Ellipticine

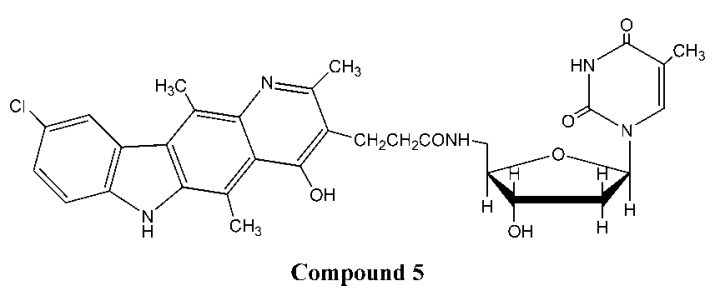

Fig. 1. Structures of Ellipticine and Compound $\mathbf{5}$ 


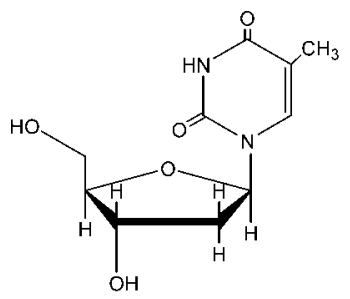<smiles>Cc1ccc(S(=O)(=O)Cl)cc1</smiles>

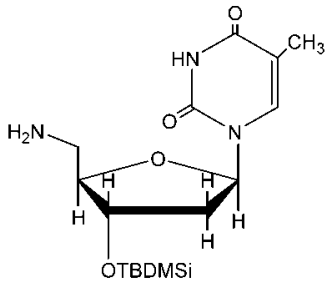

3

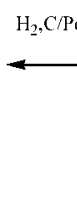

$\mathrm{NaOH} 0.1 \mathrm{M}$<smiles>CCOC(=O)CCc1c(C)nc2c(C)c3c([nH]c4ccc(Cl)cc43)c(C)c2c1O</smiles>

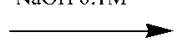<smiles>CCc1c(C)nc2c(C)c3c([nH]c4ccc(Cl)cc43)c(C)c2c1O</smiles><smiles>Cc1ccc(S(=O)(=O)OC[C@H]2O[C@@H]3[C@@H](n4cc(C)c(=O)[nH]c4=O)O[C@@H]2[C@H]3O)cc1</smiles><smiles>Cc1ccc(S(=O)(=O)O)cc1</smiles><smiles>Cc1cn([C@@H]2CO[C@H](C)O2)c(=O)[nH]c1=O</smiles>

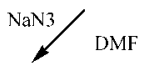<smiles>Cc1cn([C@@H](C)[C@H](C)O)c(=O)[nH]c1=O</smiles>
MMF

Chart 1 
ment, as shown in Fig. 3. Thus the lack of increase in apoptosis between treated and untreated cells may depend on p53 deficiency, as demonstrated in a previous report. ${ }^{12)}$ The present results indicate that compound $\mathbf{5}$ is potently cytotoxic in SAOS cells. Since these cells are p53 deficient, the mechanism(s) underlying cytotoxicity do not involve p53 activity. Topoisomerase inhibitors have been reported to induce the generation of hydrogen peroxide in target cells. ${ }^{13)}$ An analogous activity might be displayed by compound $\mathbf{5}$, leading to either cell necrosis or apoptosis-induced mitochondrial damage. ${ }^{14)}$ However, further investigations will be necessary to identify the interesting mechanism(s) through which compound $\mathbf{5}$ activates cytotoxicity and to determine in vivo how many prodrugs (or drugs derived from enzymatic hydrolysis $^{15)}$ are present in several organs of the guinea pig. The stability assay results demonstrated that compound $\mathbf{5}$ is stable at $\mathrm{pH} 7.4$ and was hydrolyzed slowly in human plasma and transformed in the active compound. In this way, through the carrier, it is not hydrolyzed at the peripheral level, but shows greater activity in specific tumor cells. The enzyme cathepsin hydrolyzed the carbamidic bond, giving the active compound.

\section{Experimental}

General Column chromatography was performed on silica gel (Merck, Kieselgel 40,0.063, $0.200 \mathrm{~mm}$ ). TLC analysis was carried out on Merck Kieselgel 60 F254 0.25-mm plates, visualized with UV light.

For the electrospray ionization (ESI)-MS analysis, a Waters Micromass ZQ instrument equipped with an electrospray source was used in the positive and/or negative mode. NMR spectra were recorded on Bruker WM-400 and

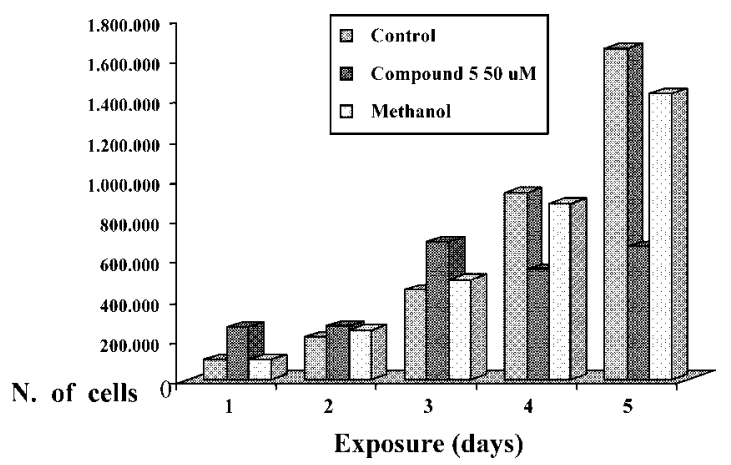

Fig. 2. Inhibition of Growth in SAOS Cells by Compound $\mathbf{5}$ and Methanol The cells were incubated for different times in the presence of the drugs $(50 \mu \mathrm{M})$ or methanol or untreated as controls and their survival was determinated by trypan blue dye staning.

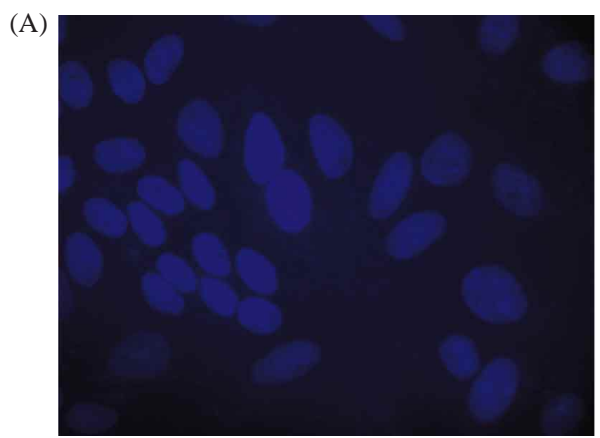

96 h compound 5 treatment on Varian-Gemini 300 spectrophotometers. All chemical shifts are expressed in ppm with respect to the residual solvent signal. $J$ values are given in $\mathrm{Hz}$. UV measurements were performed on a Perkin.

Synthesis of 2 Compound $1(30 \mathrm{mg}, 0.073 \mathrm{mmol})$ was left in contact with $730 \mu \mathrm{l}$ of a $0.1 \mathrm{~m}$ solution of $\mathrm{NaOH}$ in pyridine and stirred for $12 \mathrm{~h}$ at room temperature. The reaction was then quenched by the addition of $3.8 \mathrm{mg}$ of $\mathrm{NH}_{4} \mathrm{Cl}$, and the resulting mixture was concentrated under reduced pressure and purified on two silica gel plates eluted with $\mathrm{CHCl}_{3} / \mathrm{CH}_{3} \mathrm{OH} 9: 1$ $(\mathrm{v} / \mathrm{v})$. The band at $R f=0.2$ was scratched off the plates and eluted from silica with $\mathrm{CHCl}_{3} / \mathrm{CH}_{3} \mathrm{OH} 8: 2(\mathrm{v} / \mathrm{v})$. After drying, the eluate afforded $19 \mathrm{mg}$ ( $0.051 \mathrm{mmol}, 70 \%$ yield) of pure 2 .

Compound 2: Yellow powder. $R f=0.35$, eluent $\mathrm{CHCl}_{3} / \mathrm{CH}_{3} \mathrm{OH} 8: 2(\mathrm{v} / \mathrm{v})$. $\delta_{\mathrm{H}}\left(\mathrm{DMSO}-d_{6}, 300 \mathrm{MHz}\right) ; 11.32(1 \mathrm{H}, \mathrm{bs}, \mathrm{NH}) ; 8.29(1 \mathrm{H}, \mathrm{s}, \mathrm{H}-10) ; 7.52(2 \mathrm{H}$, overlapping signals, $\mathrm{H}-7$ and $\mathrm{H}-8) ; 3.13,2.98$, and $2.60(3 \mathrm{H}$ each, $\mathrm{s}$, three $\mathrm{CH}_{3}$ groups); $2.72\left(2 \mathrm{H}, \mathrm{t}, J=6.8, \mathrm{CH}_{2} \mathrm{CH}_{2} \mathrm{COOH}\right) ; 2.39(2 \mathrm{H}, \mathrm{t}, J=6-8$ $\left.\mathrm{CH}_{2} \mathrm{CH}_{2} \mathrm{COOH}\right) . \quad \delta_{\mathrm{C}}$ (DMSO- $\left.d_{6}, 125 \mathrm{MHz}\right): 175.32(\mathrm{COOH}) ; 145.72$, $140.84,136.72,132.96,126.43,123.69,122.96,128.80,122.65,122.34$, $120.75,116.31,116.29,116.08,112.21$ (aromatic carbons); 21.56 $\left(\mathrm{CH}_{2} \mathrm{CH}_{2} \mathrm{COOH}\right) ; 17.73\left(\mathrm{CH}_{2} \mathrm{CH}_{2} \mathrm{COOH}\right) ; 16.02,13.98$, and 11.32 (three $\mathrm{CH}_{3}$ groups). ESI-MS, $m / z$ : Found, $380.99(\mathrm{M}-\mathrm{H})$; Calcd for $\mathrm{C}_{21} \mathrm{H}_{18} \mathrm{~N}_{2} \mathrm{O}_{3} \mathrm{Cl}, 381.101$.

Synthesis of 5 Compound $217 \mathrm{mg}(0.044 \mathrm{mmol})$ was allowed to react at room temperature with $23 \mathrm{mg}(0.066 \mathrm{mmol})$ of 5-deoxy, 5-amino, 3-OTBDMS-thymidine, $\quad 34 \mathrm{mg}(0.066 \mathrm{mmol})$ of PyBop, and $10 \mathrm{mg}$ $(0.066 \mathrm{mmol})$ of HOBt dissolved in $1 \mathrm{ml}$ of anhydrous DMF containing $11 \mu \mathrm{l}(0.066 \mathrm{mmol})$ of DIEA. The reaction was monitored by TLC analysis $\left(\mathrm{CHCl}_{3} / \mathrm{CH}_{3} \mathrm{OH} 8: 2, \mathrm{v} / \mathrm{v}\right)$ and after $2 \mathrm{~h}, 2$ had completely consumed and a new product formed at $R f=0.9$.

The mixture was then concentrated under reduced pressure and purified on three silica gel plates eluted with $\mathrm{CHCl}_{3} / \mathrm{CH}_{3} \mathrm{OH} 9: 1(\mathrm{v} / \mathrm{v})$. The band at $R f=0.75$ was scratched off the plates and eluted from silica with $\mathrm{CHCl}_{3} / \mathrm{CH}_{3} \mathrm{OH} 8: 2(\mathrm{v} / \mathrm{v})$. After drying $23 \mathrm{mg}(0.033 \mathrm{mmol}, 75 \%$ yield $)$ of 4 remained, and the purity was confirmed by TLC and NMR analysis. Compound $4(23 \mathrm{mg}, 0.033 \mathrm{mmol})$ was dissolved in anhydrous THF $500 \mu \mathrm{l}$ and treated with $25 \mu \mathrm{l}(0.16 \mathrm{mmol})$ of $\mathrm{Et}_{3} \mathrm{~N} \cdot 3 \mathrm{HF}$ overnight at room temperature. The crude reaction was diluted with THF, then dried, purified on two silica gel plates and eluted with $\mathrm{CHCl}_{3} / \mathrm{CH}_{3} \mathrm{OH} 85: 15(\mathrm{v} / \mathrm{v})$. The band at $R f=0.6$ was scratched off the plates, and eluted with $\mathrm{CHCl}_{3} / \mathrm{CH}_{3} \mathrm{OH} 8: 2(\mathrm{v} / \mathrm{v})$.

The dried eluate afforded $6 \mathrm{mg}(0.010 \mathrm{mmol}, 32 \%$ yield $)$ of $\mathbf{5}$, and the purity was confirmed by TLC and NMR analysis.

Compound 4: Yellow powder, $R f=0.9$ (eluent $\mathrm{CHCl}_{3} / \mathrm{CH}_{3} \mathrm{OH} 8: 2, \mathrm{v} / \mathrm{v}$ ). $\delta_{\mathrm{H}}\left(\mathrm{CD}_{3} \mathrm{OD}, 400 \mathrm{MHz}\right): 8.03(1 \mathrm{H}, \mathrm{s}, \mathrm{H}-10) ; 7.35(2 \mathrm{H}$, overlapping signals, $\mathrm{H}-7$ and $\mathrm{H}-8) ; 7.31(1 \mathrm{H}, \mathrm{s}, \mathrm{H}-6$ thymine residue); $5.94(1 \mathrm{H}$, dd, $J=6.4$, $6.4 \mathrm{~Hz}, \mathrm{H}-1)$; $4.30(1 \mathrm{H}, \mathrm{m}, \mathrm{H}-3)$; $3.85(1 \mathrm{H}, \mathrm{m}, \mathrm{H}-4) ; 3.41\left(2 \mathrm{H}, \mathrm{m}, \mathrm{H}_{2}-5\right)$; $3.03\left(3 \mathrm{H}, \mathrm{s}, \mathrm{CH}_{3}\right.$ group); $2.90\left(2 \mathrm{H}, \mathrm{t}, J=6.8 \mathrm{~Hz}, \mathrm{CH}_{2} \mathrm{CH}_{2} \mathrm{CONH}\right) ; 2.77$ and 2.56 (3H each, two $\mathrm{CH}_{3}$ groups); $2.52\left(2 \mathrm{H}, \mathrm{t}, J=6.8 \mathrm{~Hz}, \mathrm{CH}_{2} \mathrm{CH}_{2} \mathrm{CONH}\right.$ ); $2.07(2 \mathrm{H}, \mathrm{m}, \mathrm{H}-2) ; 1.80\left(3 \mathrm{H}, \mathrm{s}, \mathrm{CH}_{3}\right.$ thymine residue); $0.87(9 \mathrm{H}, \mathrm{s}$, three $\mathrm{CH}_{3} t$-butyl group); 0.072 and $0.061\left(3 \mathrm{H}\right.$ each, s's, two $\left.\mathrm{CH}_{3}-\mathrm{Si}\right) . \delta_{\mathrm{C}}$ $\left(\mathrm{CD}_{3} \mathrm{OD}, 125 \mathrm{MHz}\right): 176.79,166.63$ (C-4 thymine residue); 152.52 (C-2 thymine residue); 134.33 (C-6 thymine residue); 111.98 (C-5 thymine residue); 148.68, 142.96, 139.17, 138.23, 128.39, 125.55, 125.17, 124.40, $122.71,118.19,117.92,117.58,113.34$ (aromatic carbons); 87.64 and 87.62 (C-1 and C-4); 74.97 (C-3); 42.95 (C-2); 41.36 (C-5); 36.71 $\left(\mathrm{CH}_{2} \mathrm{CH}_{2} \mathrm{CONH}\right) ; 26.71$ (three $\mathrm{CH}_{3} t$-butyl group); $24.06\left(\mathrm{CH}_{2} \mathrm{CH}_{2} \mathrm{CONH}\right)$;

(B)

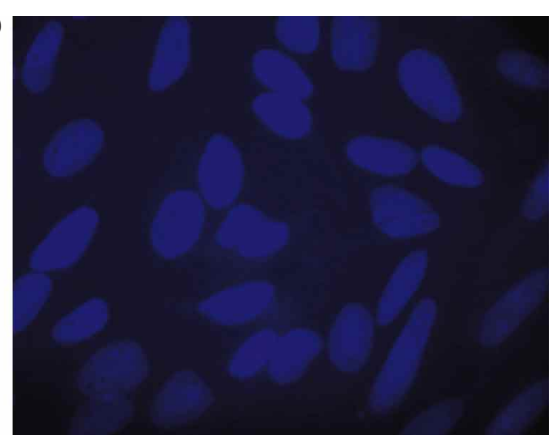

$96 \mathrm{~h}$ methanol treatment

Fig. 3. Apoptosis Induction: DAPI Staining of SAOS Cells Treated (Panel A) and Untreated (Panel B) for $4 \mathrm{~d}$ with Compound $550 \mu \mathrm{M}$ (A) or Methanol $50 \mu \mathrm{M}$ (B) 
19.26 (quaternary $\mathrm{C} t$-butyl groups); $18.78,16.97$ and 14.24 (three $\mathrm{CH}_{3}$ groups); $12.28\left(\mathrm{CH}_{3}\right.$ thymine residue); 4.15 and 4.13 (two $\mathrm{CH}_{3}$-Si). ESI-MS, $m / z$ : Found, $720.31(\mathrm{M}+\mathrm{H})^{+}$; Calcd for $\mathrm{C}_{37} \mathrm{H}_{47} \mathrm{~N}_{5} \mathrm{O}_{6} \mathrm{ClSi}, 720.298$.

Compound 5: Yellow powder, $R f=0.5\left(\right.$ eluent $\mathrm{CHCl}_{3} / \mathrm{CH}_{3} \mathrm{OH} 8: 2, \mathrm{v} / \mathrm{v}$ ). $\delta_{\mathrm{H}}\left(\mathrm{CD}_{3} \mathrm{OD}, 400 \mathrm{MHz}\right): 8.27(1 \mathrm{H}, \mathrm{s}, \mathrm{H}-10) ; 7.48(2 \mathrm{H}$, overlapping signals, $\mathrm{H}-7$ and $\mathrm{H}-8) ; 7.16(1 \mathrm{H}, \mathrm{s}, \mathrm{H}-6$ thymine residue $) ; 5.86(1 \mathrm{H}, \mathrm{dd}, J=6.8$, $6.8 \mathrm{~Hz}, \mathrm{H}-1) ; 3.90(1 \mathrm{H}, \mathrm{m}, \mathrm{H}-3) ; 3.45\left(2 \mathrm{H}, \mathrm{m}, \mathrm{H}_{2}-5\right) ; 3.15,3.04$ and 2.64 (3H each, three $\mathrm{CH}_{3}$ groups); $2.96\left(2 \mathrm{H}\right.$, dd, $\left.J=7.5 \mathrm{~Hz}, \mathrm{CH}_{2} \mathrm{CH}_{2} \mathrm{CONH}\right)$; $2.56\left(2 \mathrm{H}, \mathrm{m}, \mathrm{CH}_{2} \mathrm{CH}_{2} \mathrm{CONH}\right) ; 2.01(2 \mathrm{H}, \mathrm{m}, \mathrm{H}-2) ; 1.78\left(3 \mathrm{H}, \mathrm{s}, \mathrm{CH}_{3}\right.$ thymine residue). ESI-MS, $m / z$ : found for $\mathrm{C}_{31} \mathrm{H}_{33} \mathrm{~N}_{5} \mathrm{O}_{6} \mathrm{Cl}, 606.27(\mathrm{M}+\mathrm{H})^{+}$. Elemental analyses was performed in our analytical labs and agreed with the theoretical values within $\pm 0.4 \%$.

Stability Tests. Materials and Reagents Phosphate buffer $\mathrm{pH} 7.4$ $(50 \mathrm{~mm})$ was adjusted with phosphoric acid. Methanol was purchased from Carlo Erba (Italy) (HPLC grade). Human plasma was purchased from LAS Laboratory (Sassari, Italy). Deionized and distilled water was purified through a Milli Q system (Millipore, Milford, MA, U.S.A.).

Chemical Stability Compound 5 methanolic solution $2 \mathrm{ml}(0.5 \mathrm{mg} / \mathrm{ml})$ was added to $4 \mathrm{ml}$ of $\mathrm{pH} 7.4$ phospate buffer. The solution was maintained at $37^{\circ} \mathrm{C}$ and aliquots were withdrawn every $1 \mathrm{~h}$ for the initial $6 \mathrm{~h}$ of incubation. The possible disappearance of the prodrug was determined with HPLC analysis using the method reported below. The prodrug concentrations were determined from the calibration curve constructed by standard solutions with known concentrations (Table 1).

Enzymatic Stability A 4-ml volume of plasma was measured and a 3$\mathrm{ml}$ volume of standard solution $(1 \mathrm{mg} / \mathrm{ml})$ was added with swirling. After standing for appropriate times $(0,1,2,3,4,6 \mathrm{~h}) 1$-ml aliquots of the samples were extracted with $2 \mathrm{ml}$ of acetonitrile; the obtained suspensions were vortex-mixed and centrifuged at $3000 \times \boldsymbol{g}$ for $10 \mathrm{~min}$. The supernatant was transferred to appropriate autosamplar vials and analyzed by HPLC method reported below. The prodrug concentrations were determined from the calibration curve obtained by spiking the extracts of blank plasma samples with known concentrations (Table 2).

Analytical Procedures HPLC analysis was performed on a Lichrocart RP 18 column (particle size: $5 \mu \mathrm{m}$; $250 \times 4 \mathrm{~mm}$ i.d.; Merck, Darmstad Germany). Two isocratic elutions were used: mobile-phase $100 \%$ methanol for chemical stability and mobile-phase methanol/water $80 / 20$ for enzymatic stability, respectively. The flow rate was set at $1.0 \mathrm{ml} / \mathrm{min}$. Each sample containing the prodrug was filtered prior to injection using a Millex HV13 filter (Millipore) and an aliquot $(20 \mu \mathrm{l})$ was injected into the HPLC apparatus (Hewlett-Packard chromatograph HP 1100, automatic volume injection, and $\mathrm{DAD} / \mathrm{UV}$ detector) The prodrug was monitored at $260 \mathrm{~nm}$. The retention time was $2.7 \mathrm{~min}$. No peaks of $\mathbf{2}$ and $\mathbf{3}$ were obtained. The amounts of $\mathbf{2}$ and 3 were negligible in terms of background.

Pharmacology Ellipticine and derivative compounds are highly cytotoxic substances that kill mammalian cells at concentrations ranging from

Table 1. Chemical Stability

\begin{tabular}{cc}
\hline \hline Time $(\mathrm{h})$ & Recovery $(\%)$ \\
\hline 0 & 100 \\
1 & 100 \\
2 & 100 \\
3 & 100 \\
4 & 100 \\
6 & 100 \\
\hline
\end{tabular}

Table 2. Enzymatic Human Plasma Stability

\begin{tabular}{cc}
\hline \hline Time (h) & Recovery (\%) \\
\hline 0 & 100 \\
1 & 100 \\
2 & 100 \\
3 & 100 \\
4 & 95 \\
6 & 85 \\
\hline
\end{tabular}

$10^{-8}$ to $10^{-6} \mathrm{M}$. These compounds form molecular complexes with DNA in vitro and are able to damage the DNA of mammalian cells by inducing double-strand breaks and DNA-protein-cross links. ${ }^{16}$ ) Previous evidence suggested that ellipticine derivatives can interfere with the activity of topoisomerase II. ${ }^{17)}$ We studied the cytotoxic effects of an ellepticine derivative in human osteosarcoma SAOS cells, which lack p53, a tumor-suppressor gene product that causes cell cycle arrest in the late $\mathrm{G}_{1}$ phase and induces apoptosis by upregulation of Waf 1 and Bax genes. ${ }^{18)}$

Materials and Methods. Cell Culture and Trypan Blue Staining Cells were growth in DMEM w/o glutammine medium (Sigma Chemical Co.) supplemented with $10 \%$ fetal bovine serum, penicillin $\left(10^{5} \mathrm{UI} / \mathrm{l}\right)$, streptomycin $(0.10 \mathrm{~g} / 1)$ in a $5 \% \mathrm{CO}_{2}$ humidified atmosphere at $37^{\circ} \mathrm{C}$. The compound was dissolved in methanol, and added at various times to the cells in exponential phase of growth $\left(0.15 \times 10^{6}\right.$ cells/plate). Nonclonogenic assay cytotoxicity was studied using the trypan blue dye exclusion test. Cells were incubated for different time in the presence of $50 \mu \mathrm{M}$ of the compounds, and were incubated for 4 min with $0.25 \%$ trypan blue (Sigma Chemical Co.) and $5 \%$ fetal calf serum. Viable cells were identified by ability to exclude dye, whereas the dye diffuses into nonviable cells. Trypsin $(0.25 \%$ Boehring Mannheim) was routinely used for subculture. It was determined dose-response curves obtained from at least three independent experiments.

Nuclear Staining with DAPI To test abilities to induce apoptosis, SAOS cells were grown on glass coverslips, after treatment rinsed in phosphate buffered saline (PBS) fixed in paraformaldehyde for $20 \mathrm{~min}$ at room temperature, the coverslips were incubated at room temperature in a solution of diamino-2-phenyl-indole (DAPI), after $30 \mathrm{~min}$, they were washed three times in water and put on a glass slide, using Mowiol.

Acknowledgment We Thank Dr. M. Nieddu for helpful collaboration.

\section{References}

1) Wang J. C., Annu. Rev. Biochem., 65, 635-692 (1996).

2) Monks N. R., Blankey D. C., East S. J., Dowell R. I., Caluete J. A., Curtin N. J., Arris C. E., Newell D. R., Eur. J. Cancer, 11, 1543-1552 (2002).

3) Lancelot J. C., Letois B., Rault S., Dung N., Saturnino C., Robba M., Gaz. Chim. Ital., 121, 301-307 (1991).

4) Moinet V., Tabka T., Poulain L., Godard T., Lecheurel M., Saturnino C., Lancelot J. C., Le Talaer J., Gauduchon P., Anti-Cancer Drug Design, 15, 109-118 (2000).

5) Moinet V., Tabka T., Sichel F., Gauduchon P., Le Talaer J., Saturnino C., Lancelot J. C., Robba M., Eur. J. Med. Chem., 32, 113-122 (1997).

6) Moinet V., Tabka T., Gauduchon P., Le Talare J. Y., Lancelot J. C., Letois B., Saturnino C., Rault S., Robba M., J. Toxicol. Clinique Exp., 1, 3-4 (1992).

7) Teran C., Santana L., Teejeira M., Uriarte E., De Clarcq E., Chem. Pharm. Bull., 48, 293-295 (2000).

8) Wueest T., Gerlach E., Banbrjee D., Gersjach D., Pfizenmaier K., Oncogene, 9, 844-849 (2002).

9) Kao C. K., Waki A., Sassaman M. B., Jagoda E., Srajek L. P., Ravasi L., Shimoji K., Eckelman W. C., Nucl. Med. Biol., 29, 527-535 (2002).

10) Hergueta A. R., Fernandez F., Lopez C., Balzanini J., de Clarcq E., Chem. Pharm. Bull., 49, 1174-1177 (2001).

11) Gumina G., Song G. Y., Chu C. K., FEMS Microb. Lett., 202, 9-15 (2001).

12) Sugikawa E., Hosoi T., Yazaki N., Gamanuma M., Nakanishi N., Ohashi M., Anticancer Res., 19, 3099-3108 (1999).

13) Mizutani H., Tada-Oikawa S., Hiraku Y., Oikawa S., Kojima M., Kawanishi S., J. Biol. Chem., 277, 30684-30689 (2002).

14) Owuor Ed., Kong An., Biochem. Pharmacol., 64, 765-770 (2002).

15) Maeda H., Sawa T., Konno T., J. Controll. Release, 74, 47-61 (2001).

16) Ferlin M. G., Chiarelotto G., Marzano C., Severin E., Baccichetti F., Carlassare F., Simionato M., Bordin F., Il Farmaco, 53, 431-437 (1998).

17) Monnot M., Mauffret O., Simon V. Lescot E., Psaume B., Sacier J. M., Charra M., Belehradek J., Jr., Fermandjian S., J. Biol. Chem., 266, 1820-1829 (1991).

18) Ryan J. J., Danish R., Gottlieb C. A., Clarke M. F., Mol. Cell. Biol., 13, $711-719$ (1993) 